Article

\title{
The Bestial Feminine in Finnegans Wake
}

\author{
Laura Lovejoy
}

School of English, University College Cork, Cork, Ireland; laura.lovejoy@ucd.ie

Received: 10 June 2017; Accepted: 31 July 2017; Published: 4 August 2017

\begin{abstract}
Female characters frequently appear as animals in the unstable universe of James Joyce's a Finnegans Wake. What Kimberly Devlin terms "the male tendency to reduce women to the level of the beast" is manifest in Finnegans Wake on a large scale. From the hen pecking at a dung heap which we suppose is a manifestation of matriarch Anna Livia Plurabelle, to the often lascivious pig imagery (reminiscent of Bloom's experience with brothel-keeper Bella in the "Circe" episode of Ulysses) associated with juvenile seductress Issy, the lines between animal and human are frequently blurred when it comes to representing the feminine in the Wake. As scholars such as Devlin have highlighted, such constellations of images have their roots in blatantly misogynistic iconographies. Indeed, the reinscription of female characters into bestial roles in the Wake echoes a religious history of the dehumanisation of women. Yet, while this gendered representational tendency has been noted in Joycean and, more recently, wider modernist studies, its deployment and impact as a cultural and literary trope has not yet been interpreted according to the sociohistorical and cultural contexts which shaped the composition of Finnegans Wake. In particular, the culturally-specific sexual politics of Free State Ireland (1922-1937), against which Joyce arguably pushes throughout the entirety of the Wake, offer a suggestive lens through which to view the text's interconnected representations of the feminine and the bestial. This article suggests that, in Finnegans Wake, the nonhuman is a mode through which Joyce explores the fraught sexual politics of early twentieth-century Ireland. Specifically, the bestial feminine becomes an avenue to inspect, expose, and satirise prevalent contemporary fears over female sexual licentiousness and national moral decline. Historicising the text's grappling with themes of carnality and baseness, the article discusses the ways in which the woman-as-animal is deployed in Finnegans Wake as a grotesque symbol of an unbridled and threatening female sexuality-an extreme embodiment of 1920s and 1930s Ireland's worst fears surrounding the perceived degeneration of Irish women's modesty. Unearthing the Wake's social contexts in order to interpret its sexual politics, this article ultimately asks whether the trope of the woman-as-animal stages a complete resistance against the conservatism of early twentieth-century Ireland's sexual politics, or whether Joyce's invocation of a historically misogynistic and patriarchal construction risks reinforcing the dehumanisation of women, moving the text's sexual politics further away from the liberatory.
\end{abstract}

Keywords: James Joyce; animals; women; sexual politics; gender; modernism

Therefore wherever it is possible, and so far as it is possible, the male is separated from the female. For the first principle of the movement, whereby that which comes into being is male, is better and more divine, and the female is the matter... While the body is from the female, it is the soul that is from the male.

—Generation of Animals (Aristotle 1984, p. 1146)

The Aristotelian distinction between male rationality and female matter has had repercussions for Western philosophy since its inception, manifesting in the repeated alignment of women with the natural, and therefore the animal, world. As Siri Hustvedt remarks in her consideration of the gender implications of the persistent mind/body dualism, "this stubborn division and its attendant 
associations have reverberated throughout the centuries and refused to die" (Hustvedt 2016, p. 206). The pervasive, gendered dualism Hustvedt speaks of is necessarily hierarchical, positioning women, nature, and animality, part of the same bodily and material category, as inferior to men, who contain the nobler qualities of the soul and the spirit. Despite Aristotle's attempts to demystify the relationship between human and animal life through the creation of such hierarchies, the subject of men's relationship to animals has remained a preoccupation in philosophy and the natural sciences, re-emerging and inflecting Medieval, Enlightenment, and modern thinking. Furthermore, the Western philosophical fascination with the relationship between men and animals has never been uncoupled from investigations into the relationships between non-human animals. As Gilles Deleuze and Felix Guattari note in Mille Plateaux, "the relationships between animals are bound up with the relationships between man and animal, man and woman, man and child, man and the elements, man and the physical and microphysical universe" (Deleuze and Guattari 2014, p. 274). Yet, Deleuze and Guattari are also careful to remind us that "the relationships between animals are the object not only of science but also of dreams, symbolism, art and poetry, practice and practical use" (Deleuze and Guattari 2014, p. 274). Indeed, animals are a near ubiquitous presence in Western literature, appearing symbolically, through metaphor, and in anthropomorphised forms. Given the tangible influence of Aristotle's gendered hierarchy, and the enduring association of women with animality, it seems obvious that any literary work preoccupied with the relationship between animals and humans or, more specifically, which represents women as animals or animal-adjacent, must negotiate with the history of this patriarchal dualism, operating within its boundaries, whether it seeks to destabilise, reinforce them, or repurpose them to subversive ends. Certainly, the interpretation of bestial women in literature cannot be removed from a cultural tradition which assigns women, animals, and the woman-as-animal a negative and inferior value. By the same token, however, Joyce's Finnegans Wake (1939) is a literary text illustrative of the subversive potential of the trope of woman-as-animal, and is evidence of the importance of context in considering the deployment of female animal imagery for or against patriarchal narratives. Deploying a range of animal avatars for its primary characters, Finnegans Wake is a text in which the relationship between humans and animals is a key preoccupation (Joyce 2002). The Wake is as concerned with the relationships between animals as it is with the relationships between humans and animals, and animals often stand in for human characters in the text's staging of conflicts, as Margot Norris has argued (Norris 2014). But the text is also particularly notable in its routine depiction of women as animals, often linking female characters with animals that carry stereotypical associations both of degraded femininity and sexual precocity. The inscription of female characters into animalistic modes often has the effect of reducing them, as Kimberley Devlin argues, "to the level of the beast" (Devlin 1991, p. 129). Yet, while connotations of inferiority must always be considered in depictions of human beings as animals, particularly women, the bestial also invites us to consider that which is liminal, transgressive, and outside the boundaries of human directives-those very strictures which are under attack in Finnegans Wake. The focus of this article is the representation of women as animals in Finnegans Wake. Exploring how the woman-as-animal might illuminate aspects of the text's engagement with the sexual politics of the period in which it was written, the Irish Free State, this article considers both how the representation of women as animals in the text may echo patriarchal constructions of feminine atavism and inferiority, while ultimately deploying the bestial woman as a signifier of potent female sexuality which cuts against Free State and Catholic demands of female purity.

In her 2014 article "The Animals of James Joyce's Finnegans Wake", Norris notes the relative absence of scholarly discussions of the presence of animals in Joyce's most meaning-resistant work. Norris argues that the animals in Finnegans Wake "merit further attention not only for their numerous appearances in wordplay, puns, and allusions, but also for their thematic roles as figures, characters, and signifiers, all of which serve to enhance and deepen the ecological vision of this 1939 dream-work" (Norris 2014, pp. 527-28). The metaphorical and literal livestock, pets, and wild animals which populate the pages of Dubliners, A Portrait of the Artist as a Young Man, and Ulysses have received 
more consistent and focused attention than the bestiality of the Wake, despite its deeper breakdown of the boundaries between dreams and reality, animate and inanimate, and human and nonhuman (Haas 2014; Rando 2009). As Finn Fordham notes, for many, including the earliest Wake scholars, such as Joseph Campbell, the text is a "vast dream ... where the dead can speak, where humans are animals and vice versa" (Fordham 2007, p. 12). For Norris, whose detailed consideration illuminates the Joycean strategy of deploying insects, birds, and other beasts as signifiers in human struggles, the function of the animal is "part of the Wake's project of setting human cultural figures and narratives into the much larger horizon of the spiritual world, on the one hand, and the natural world, on the other" (Norris 2014, p. 527).

Given the historical association between women and animals in Western philosophy, it is surprising that scholars have so far overlooked the gendered aspect of the Wakean deployment of bestiality. The planes of existence Joyce aims to access and integrate further into human cultural experience via his deployment of animal avatars do not exist free of gendered associations, nor do the animal metaphors he uses. Each of the text's primary characters, who are members of the Porter/Earwicker family, is subject to non-human representation at one point or another. Yet the text's women-animals, appearing in the forms of sows, heifers, bitches, hens, foxes, rabbits, and kittens, often convey recognisable patriarchal constructions of femininity; their various appearances as pets, farmyard, and wild animals conjure dominant articulations of femininity as servile and exploitable, docile and infantile, in need of controlling and domestication, or, in a more liberatory mode, sexually licentious.

The link between women and animals is manifest in Finnegans Wake on a grand scale. The patriarch as earwig (Humphrey Chimpden Earwicker) may not be a recognisable trope, yet the matriarch as hen surely is. Earwigs are associated with eavesdropping, as the colloquialism "earwigging" indicates. Yet this does not convey stereotypical constructions of masculinity, nor societal attitudes towards men or patriarchs. "Earwig" is not recognisable as a derogatory term for men. By contrast, the "old biddy" who "henpecks" her husband is a familiar metaphor, and one whose cultural connotations the Wake replicates: the "cearc" (Irish for hen, FW 11.27) which appears close to the start of the text is a creature valued primarily for her reproductive capacity and role in providing sustenance. ${ }^{1}$ She is also a manifestation of Anna Livia Plurabelle, the core matriarchal presence in the text. The wife of HCE and also the life-giving River Liffey, she is first introduced as a hen or little "gnarlybird" (FW 10.31) scavenging a heap of dung. The "littleness" of the bird is emphasised, as well as the repetitiveness of her pecking motions. Whether or not she seeks scraps of food or the letter written by ALP which will later vindicate her husband, accused of a sexual crime in Phoenix Park, is irrelevant; although she later morphs into a more recognisable human female, and eventually a river, here she is a creature devoted to the singular task of scavenging the "midden heap" or "middenhide hoard" (FW 19.10) and protecting her fallen husband and dependent children.

"Biddy", the hen, eventually uncovers the letter written by ALP which is supposed to vindicate her husband. But at this early stage in the text it appears that she knows little, eats little, has little, and is little: "there's that gnarlybird ygathering, a runalittle, doalittle, prealittle, pouralittle, wipealittle, kicksalittle, severalittle, eatalittle, whinealittle, kenalittle, helfalittle, pelfalittle gnarlybird." (FW 10.31). She continues to peck at the dung heap, blurring the boundaries between the categories of domestic fowl and pet, as the textual voice mimics the coaxing phrase uttered by pet owners, "here pussy pussy", also invoking her daughter, Issy, who is associated with pussycats throughout the text. Biddy is "picking here, pecking there, pussypussy plunderpussy" (FW 11.11). "Pussy", of course, has obvious sexual connotations, being slang for female genitalia, in addition to invoking cat-like characteristics associated with female sexuality such as coyness and slyness. These are characteristics attributed to the

1 The reference (Joyce 2002) will be cited as $F W$ with the corresponding page and line numbers (e.g., 11.27, page 11, line 27) in keeping with the conventions of the Faber \& Faber edition. 
character Issy, often presented as a juvenile temptress. Mother and daughter, although they represent different forces in the text, are sometimes aligned with one another, morphing into the same figure. As Chrissie Van Mierlo notes, "in the Wake, concrete character determinations and distinctions cannot entirely hold good" (Van Mierlo 2017, p. 75). Here, Biddy the hen/ALP's accompanying refrain of "pussypussy", with its infantile sound and invocation of cats and female genitalia, also links her to her adolescent or child daughter. Similarly, Issy's sexually lascivious "lovelilitters" (FW 459.23), as I will discuss later, align her with a more mature, maternal sexuality, illustrating the malleability of roles in the Wake.

ALP emerges from a matrilineage of domestic animals, it seems. She recalls, in a strangely contradictory image, a "fallow coo" (FW 204.20) under whose udder she took shelter during her infancy, and later identifies her mother as a cow or the Egyptian sky goddess Nut, who took the form of a cow (FW 627.89). Here, ALP-Biddy conforms to the stereotype of the older woman who "hen pecks" her husband. In fact, the text later makes this explicit when HCE is described as "the kenspeckled souckar" (FW 362.15) as well as ALP's "handpicked hunsbend" (FW 364.36). These unflattering descriptions of the Earwicker marriage occur in chapter II.3 where, following the account of HCE's fall from grace and its aftermath in chapters 1.2-4, the narrative offers an account of HCE's life as a publican. Embarrassing details of the patriarch's personal history are revealed in four oral pub stories. Following the raucous skit performed by stage Irishmen Butt and Taff (FW 338-54), HCE is described by the patrons as "husband of your wifebetter" (FW 356.9) and "that old offender" (FW 356.13), reinforcing textual associations between $\mathrm{HCE}$, violence, and criminality. The intimation of his violence towards ALP is further reinforced by later descriptions of her as a submissive animal. In the scene describing HCE and ALP's copulation in chapter III.4, ALP becomes a mare for her husband HCE to ride, betraying a patriarchal conceptualisation of sex as dominance and control. Here, sex is configured as riding and a female domestic animal is ridden by a male, much to his delight; HCE is a "galleonman jovial on his bucky brown nightmare" (FW 583.8-9). ALP as a pecking hen is the preliminary example of the woman-as-animal trope in Finnegans Wake, and is one of many.

The text's male characters are of course subject to bestialisation, too; twin brothers Shem and Shaun appear as insects, snakes, and a range of other creatures with historical and metaphorical significances. Yet the text's images of bestial women come loaded with historical stereotypes of degraded, subservient, and deviant femininity. The female-gendered animals in the text warrant further inspection, specifically in terms of their correspondence to prominent metaphors of woman-as-animal which have long been deployed as part of patriarchal articulations of femininity. Additionally, the deployment of the woman-as-animal metaphor takes on new significances when viewed in relation to the context in which the Wake was written and which it addresses-The Irish Free State (1922-1937). Reading these images against the backdrop of the Irish Free State further reveals the dynamics by which the text absorbs, refracts, and pushes against the sexual politics of its time. In the context of an explicitly censorious and conservative social and political milieu in which female chastity, purity, and the maternal body were valorised and sexual licentiousness systematically denigrated, the trope of woman-as-animal takes on subversive significance.

\section{"Woman as Animal"}

Ecofeminist scholars have repeatedly identified the Aristotelian mind/body dualism and the related gendered separation between rationality and nature as a root of the inferiorisation and bestialisation of women in Western thought, an ideological basis which persisted at least into the late twentieth century. Writing in 1993, Val Plumwood noted that "the connection between women and nature and their mutual inferiorisation is by no means a thing of the past" (Plumwood 1993, p. 21). Plumwood argued that

as in Aristotle's [Politics], the gulf between the rational and the non-rational, and the inferiority of the latter, can be used to support the supposed inferiority of not just women, but also of slaves, people of other races and cultures ('barbarians') and those who perform 
manual as opposed to intellectual tasks. All of these can be treated as less rational and as closer to the sphere of nature, and especially as closer to animality.

—(Plumwood 1993, p. 47)

One method of what Plumwood terms "the inferiorisation of human qualities and aspects of life associated with necessity, nature, and women" has been the explicit identification of women with animals through metaphor (although from the nineteenth century onwards the hierarchisation of gender was increasingly legitimated by "findings" in pseudo-sciences such as anthropometry) (Plumwood 1993, p. 21).

The social force of animal metaphor applied to women has long been a tool of patriarchal dominance. As Joan Dunayer notes, "language is a powerful agent in assigning the imagery of animal vs human" and, like many metaphors, the woman-as-animal is "charged with an ideological or attitudinal component" (Dunayer 1995, p. 11; Donovan 2016, p. 78). Existing as a "major patriarchal epithet" for centuries, the "Woman as Animal" trope serves to reinforce female inferiority, whether the metaphor is positively, or (more often) negatively charged. Such metaphors often communicate ugliness and low social value (such as "dog" and "cow") or, in certain cases, sexual desirability and attractiveness (such as "chick" and "kitten") (Dunayer 1995, p. 12). In each instance, however, the metaphor emphasises women's inferior and subservient position in relation to men and is part of a process of othering.

As Josephine Donovan notes, in patriarchal societies, the feminised animal is "an abject creature, upon whom are ascribed aspects of otherness." It is through the sacrifice of this feminised animal, Donovan notes, that access to the sacred is achieved" in traditional patrilineal societies (Donovan 2016, p. 184). Somewhat paradoxically, given the violence and the abjection ascribed upon the feminised animal, the animal is associated with the sacred, a phenomenon which appears to contradict the Aristotelian relegation of the female and the animal to the non-spiritual realm of matter.

In common with a number of feminist and ecocritical scholars, Diane Antonio also links the "oft-made identification of women with the 'inferior' natural functions" to Aristotle's characterisation of the female role in reproduction as deficient in spirit or life principle. In Aristotle's view, Antonio writes, the female transmitted "only dumb, inferior matter" (Antonio 1995, p. 221). This inferior positionality reinforces the woman's status as an animal and an object, existing in a separate category to the white, "rational" male-what Plumwood terms "the western human ideal" (Plumwood 1993, p. 25). The conceptualisation of women as animals in culture, writes Devlin, "perpetuate[s] the convenient conceptual categorization of woman-as-object" (Devlin 1991, p. 129). Indeed, woman-as-object has been central to second-wave feminist analyses of the relationship between women and animality; the basis for Carol J Adams' ecocritical feminist exploration of the nexus between sexism and meat consumption is her acknowledgement that "women and animals are similarly positioned in a patriarchal world, as objects rather than subjects" (Adams 1990, p. 168).

The three primary animal categories with which women have most often been identified in the English language are domestic/farmyard animals, pets, and wild animals. Descriptions of women as domestic animals or livestock often reinforce the sense of women's confinement to the domestic sphere and their value as providers of food. Servitude and edibility are central to the metaphoric identification of women with farm animals and, despite the centrality of domestic animals to human economies, comparing women to domestic animals frequently carries a denigrating, rather than an exalting, force in the English language. As Dunayer continues, quoting Robert Baker, comparisons between women and domesticated animals are offensive in at least one way because they "reflect a conception of women as mindless servants" (Dunayer 1995, p. 15). Comparing women to hens, for example, "communicates scorn because hens are exploited as mere bodies-for their egg-laying capacity and flesh" (Dunayer 1995, p. 12). Farmyard animal metaphors paradoxically focus both on women's economic use value and their undesirability. In addition to emphasising female servitude, the use of farmyard metaphors serves to sexually devalue or castigate women, often implying unattractiveness and obsolescence, or unacceptable sexuality, in contrast to the exploitable fertility also associated 
with livestock. As Irene Lopez Rodriguez remarks, “in both English and Spanish pig and its female counterpart sow /Cerda are metaphorically used as terms of opprobrium for a woman, implying fatness, dirtiness, ugliness, and even promiscuity" (Rodriguez 2009, p. 88). Livestock metaphors can denigrate women by reducing them to their reproductive capacities and casting them in servile roles. As Dunayer highlights, "references such as hen (first used to refer to women and/or wives in the seventeenth century), cow (also first recorded in reference to women in the late seventeenth century), and bitch emphasize the exploitation and denigration of women for their reproductive capacities as well as disrespect for them" (Dunayer 1995, p. 18). Despite the benevolent attitude towards pets encapsulated in the use of the word "pet" as a term of endearment and the characteristics of loyalty and sociability attributed to dogs, the archetypical pet, the terms "dog" or "bitch", when applied to women, are often explicitly negative, implying ugliness, promiscuity and unpleasantness.

However, in addition to the negative connotations often conveyed by pet metaphors when applied to women, such metaphors can connote sexual attractiveness, playfulness or desirability - characteristics which undermine certain patriarchal models of feminine sexual purity, as in the case of "kitten". Although the phrase "sex kitten" did not enter the English lexicon until 1958, cats and kittens have long been associated with female sexual playfulness and precocity, at times in negative or derogatory terms. As Lopez Rodriguez notes, "negative traits prevail in the figurative usage of cat ... cats have a reputation for being independent and even treacherous...in English cat denotes a malicious woman, a loose woman and a prostitute" (Rodriguez 2009, p. 84). It is also noteworthy, however, that both dogs and cats, as familiars, are associated with witches, and thus also convey threatening and transgressive femininity and sexuality.

Livestock and pets are both dependent on human beings for their survival, with pets fulfilling a servile role and serving a need for companionship, and livestock constituting an exploitable commodity which is favourable to human economies. The frequent application of livestock and pet metaphors to women, therefore, reinforces women's dual subservient and dependent position in society, either portraying them as vessels valued for their reproductive capacity, unattractive creatures who are no longer sexually viable, or unthreatening, inconsequential playthings. The woman as wild animal, however, carries decidedly different connotations. The fox or vixen carries the same connotations of sexual promiscuity as the kitten, but, unlike the pet, the wild female animal constitutes an even more threatening presence. The woman-as-wild-animal metaphor/trope reinforces women's association with nature, animality, and baseness and, rather than rendering woman a commodity to be exploited, dominated and "mastered", the wild animal metaphor presents the woman as a potentially threatening, notably sexualised force.

Bestialisation is of course a tactic of marginalisation which has been applied to numerous historical "others", not just women. Indeed, as Lopez Rodriguez writes, animal metaphors operate as a "conventional way of categorizing otherness" in general (Rodriguez 2009, p. 79). Christopher Peterson notes that "the transposability of the animal trope enables its application to a broad range of literary, cultural, and historical contexts" (Peterson 2013, p. 16). History is replete with the bestialisation of excluded populations such as "women, queers, Jews, Arabs, poor people, and indigenous peoples on virtually every continent" (Peterson 2013, p. 16). Historical comparisons between marginalised populations and animals also extend beyond metaphor, as the proliferation of nineteenth-century pseudo-sciences in support of theories of biological and cultural degeneration illustrates. The deployment of animal comparisons as part of scientific racism served to reinforce the marginality of colonised populations at the hands of the British Empire throughout the nineteenth century, for example, and the tactic of bestialisation formed a core part of the degeneration theories which gained traction in the cultural landscape of nineteenth century Europe (Chamberlin and Gilman 1985). The conflicts staged in Finnegans Wake, a text which set itself the modest task of providing a "universal history", are inseparable from a world shaped by such dualisms (Fordham 2007, p. 27). In the Wake, bestialisation can serve as a textual reminder of the historical "otherness" of women, whether or not the text seeks to reinscribe or resists that otherness. This 
otherness, signaled by animality, is often invoked at the moments the text responds to the specific constructions of acceptable womanhood which were propagated in the public discourses of the Irish Free State.

The instability of character in Finnegans Wake explains in part the ease with which female (and male) characters are rendered as animals in the text, and also highlights the difficulties inherent in interpreting animal transformations as separate from any other Wakean transformations. Character, physical form, time and space are all subject to routine disrupt in the Wake. ALP, for example, in addition to appearing as a host of farm animals, also appears in the form of a river, while HCE is a publican, an earwig, a sleeping giant, and even a land mass; Howth head is his sleeping body while the Wellington monument in Phoenix Park—the "big Willingdone mormorial" (FW 6.34-5)—is his penis. The Earwickers' twin sons, Shem and Shaun, an ideologically opposed duo who are also, at times, interchangeable, morph into an ant and a grasshopper in the fable of "the Ondt and the Gracehoper" (FW 414.20-21) and variously embody mythological, historical, and political figures such as Cain and Abel, St. Patrick, St. Kevin, and Eamon de Valera. Animal transformations, therefore, must be interpreted as part of the wider web of metamorphoses in the text; any character, at any time, is subject to representation in the form of an animal. The sociohistorical contexts that the Wake addresses, one of which is the Irish Free State, however, can reveal aspects of the patriarchal and/or subversive function of the animal metaphor when applied to women.

\section{Finnegans Wake: A Free State Text}

In the public, religious, and journalistic discourses of the Free State, the qualities of purity and chastity were not only valorised, but explicitly connected to the future of the nation-state. The failure of citizens and, in particular, women, to uphold the virtue of purity was catastrophised in the increasingly ubiquitous Catholic social purity rhetoric which shaped the moral landscape of the newly independent state. Indeed, the Irish Christian Brothers declared in a 1924 advertisement for their magazine Our Boys that "purity is the national virtue of Ireland" (The Irish Christian Brothers 1924). In a 1926 sermon, the Rev. Dr. Gilmartin, archbishop of Tuam, took the idealisation of a distinctly feminised trait, purity, a step further by stating that "the future of the country is bound up with the dignity and purity of the women of Ireland" (Luddy 2007, p. 194). Maryann Valiulis has identified the ways in which the iconographic ideal of Republican motherhood, essentially conflated with womanhood in the Free State, was used to valorise the qualities of "self-effacement ... meekness [and] indirectness" in women (Valiulis 1995, p. 118). It is worth noting here that the moral landscape of the Free State was shaped by the traditions and more recent developments of the Church in Rome, particularly with regards to the censorship of morally damaging publications. As Van Mierlo remarks, the Wake acknowledges this influence when it "conflates Irish and continental modes of Catholicism in a playful manner" (Van Mierlo 2017, pp. 80-81).

According to the Catholicised ideology of the new state, all citizens were conceptualised as servants of the biopolitical state, upholding Catholic moral standards in the service of a culturally and morally distinct independent Ireland. Women were valued largely for their adherence to codes of purity, self-effacement, and the often self-regulated restriction of their visibility in public life, coupled with a commitment to operating primarily within the domestic sphere. The 1937 constitution, in many ways the culmination of Eamon de Valera's social policies throughout the years of the Free State, enshrined women's domestic and reproductive value in Irish society and the economy. While the valorisation of female modesty was one aspect of the Free State designation of acceptable womanhood, another aspect was the idealisation, in public, religious, and legislative discourse, of the maternal body. The fetishisation of female chastity and purity fed into the post-independent State's ambivalent relationship with the maternal body, as Gerardine Meaney has illustrated. The simultaneously natalist and social purist ideology of the Irish state resulted in the "often violent rejection and repression of the maternal body" (Meaney 2010, p. 10). Meaney's work explains the ways in which "motherhood was overtly idealized and venerated in its social and religious aspects, but also ruthlessly demonized 
if it occurred outside the legalities and control of church and state" (Meaney 2010, p. 10). Thus, the Free State was a sociosexual milieu in which acceptable womanhood fell broadly into two categories: chaste and "pure" femininity, and self-sacrificing, maternal womanhood.

These narrow constructions of femininity mirror the female qualities valorised in a range of postcolonial and nationalist contexts across multiple geographical and temporal boundaries, as work by Nira Yuval Davis and Floya Anthias illustrates (Yuval-Davis and Anthias 1989). Yet, the particular ambivalences which pervaded these constructions were in many ways culturally specific to the Irish Free State. Additionally, it is unsurprising that, given the emphasis on women's servility and reproductive value across disparate patriarchal societies, the characteristics valorised in the Free State also mirror the qualities associated with the animals that women are most frequently compared to in patriarchal societies.

As Free State legislators and religious leaders publicly bolstered paradigms of acceptable womanhood, Joyce was drafting Finnegans Wake, observing the cultural and political life of the Free State from a distance. The compositional history of the Wake corresponds almost precisely to that of the Irish Free State. Joyce began composing fragments of Work in Progress, which would later become Finnegans Wake, as early as 1923, and the text was published just two years after the ratification of the Irish Constitution and its transition to a Republic in 1937. As genetic histories of the text show, Joyce continued redrafting and revising up until the text's publication, incorporating fragments of Irish public and journalistic discourse that he had accumulated fastidiously throughout the 1920s and 1930s (Fordham 2007; Slote and Crispi 2007). Thus, Finnegans Wake addresses not just the year of its publication, but acts as a retrospective late modernist look at the first two decades of Irish independence.

Joyce's first documented response to the Irish Free State was to decline an invitation to live there. In March 1922, a month after the publication of Ulysses, Desmond Fitzgerald, the Irish Minister for Information, asked Joyce if he would consider returning to Ireland now that the country was on the brink of independence. Joyce replied: "Not for the present" (Ellmann 1983, p. 534). Joyce was in Paris, developing sketches for Work In Progress. In April 1925, when he was asked by French journalist Simone Téry to describe his attitude toward the national movement in Ireland, he replied "To use an expression of your country, $j^{\prime}$ en ai marre [I'm fed up with it]" and stated that he "didn't think anything" about Irish self-governance (Jolas 1949, p. 189). Contrary to his dismissive remarks about the question of his living in the newly postcolonial state, the ongoing engagement with 1920s and 1930s Irish politics and culture in Finnegans Wake makes it clear that the Free State was a central preoccupation for Joyce throughout the composition of the text. It is also evident that, from the beginning, Joyce conceived of Finnegans Wake as a critique of authority. The initial sketches for Work in Progress, drafted in 1922, played with the theme of the fall from power (Hayman 2002, p. 6).

Although written largely from Paris and Zurich, the Wake is deeply anchored in the cultural and political landscape of Free State Ireland. The Civil War and its aftermath, Eamon de Valera's role as a political leader, the state of nationalism in postcolonial Ireland, and the cultural and sexual politics of the fledgling nation-state are all addressed in the text. In particular, the Wake openly skewers the increasingly visible, organised, and powerful brand of Catholicism which now acted as the nation's key social and moral powerbroker, through the pious figure of Shaun, a paragon of Catholic zealotry and an obnoxiously nationalist discipline/manifestation of De Valera. In Shaun's violent and incestuous sermon to his sister Issy in section II.3, as in numerous other sections of the book, Joyce emerges as an unquestionable critic of the sexual mores of the Free State, positioning himself against conservatism and the forces of social purity which would seek to restrain both male and female sexual behaviour. How, then, does the woman-as-animal, a trope with both sexist connotations and anti-authoritarian potential, fit into a text which is ostensibly driven by a need to critique authority? 


\section{The Wake's Female Animals}

In Finnegans Wake it is often difficult to distinguish metaphor from symbolism, anthropomorphism or surrealist narratives of transformation. In Joyce's earlier works, women are compared to or treated like animals by male characters, betraying, as Devlin argues, "a male resistance to acknowledging female subjectivity" (Devlin 1991, p. 129). In these earlier texts, the use of metaphor is clearer, as is the subject-position from which the animal comparison emerges. The sexist Blazes Boylan compares a woman to a "young pullet" (U 10.327) in his interior monologue in the "Sirens" episode of Ulysses, and the limited imagination of Stephen Dedalus appears capable only of either exalting or degrading women, even as he apparently experiences an epiphany when a "bird girl" is revealed to him on Sandymount strand (P 152). ${ }^{2}$ Yet, as Devlin notes, such restrictive constructions of femininity form part of Joyce's critique of the male inability to acknowledge female subjectivity (Devlin 1991, p. 129), and this critical strand of the Joycean imagination persisted, shaping the composition of Finnegans Wake.

Only the surrealist dream sequence in the "Circe" episode of Ulysses approaches the Wake's distortions of the laws of physics and the boundaries between animal and human. In Ulysses, the pig-as-woman initially construes male sexual desire as hunger, and sex as eating. As Bloom follows an attractive woman to the butcher's, he watches her "moving hams" ( $U$ 4.172). The association between pigs and women recurs later in the "Circe" episode of the novel, when Bloom transforms into a pig woman and is ridden by the cruel brothel mistress Bella/Bello. For Bloom, a sexual masochist, dual bestialisation and feminisation are the ultimate subjugation and humiliation. Bloom is lowered not just by his transformation into a pig, but into a woman - he must transform into a woman, descending to the level of the beast, to complete his devolvement. Here, according to an Aristotelian dynamic, Bloom moves from the rational, male sphere of the soul to the base, female sphere of the body, matter, and animality. As Maud Ellmann writes,

In the psychodynamics of [the Circe] episode, to be changed into an animal is equivalent to being changed into a woman, born to be bitted, bridled, and mounted. Thus Bloom turns into a pig-woman in order to be whipped as a circus animal by Bello, the whoremistress who turns into a man.

-(Ellmann 2006, p. 90)

While Bloom's feminisation in "Circe" has been read as transgressive, even feminist, Ellmann makes the point that the episode "could be read as an exorcism in which Bloom and Stephen externalise their femininity in order to get rid of it, Bloom by acting out the role of the humiliated pig-woman" (Gibson 1994, p. 12; Ellmann 2006, p. 90).

Female characters appear not just as domestic animals, livestock and pets in Finnegans Wake, but as wild animals, too. A large number of feminised animals appear in relation to the primary characters of ALP and Issy in multiple languages throughout the text. Filly, for example, appears as "phillippy" (FW 9.1) and "schoolfilly" (FW 101.16), dog/bitch appears as "hond" (FW 4.29), "dogfox" (FW 30.18), "snorler" (FW 37.12), and "bitches" (FW 60.15), sow appears as "porca" (FW 9.36), "truie" (FW 88.12), and troia (FW 381.31), hen appears as "hin" (FW 12.17), "kip" (FW 76.19), "gallina" (FW 184.13) and "poule" (FW 192.13), kitten appears as "muschi" (FW 96.12), "pussy" (FW 275.1), "kisse" (FW 361.16) and "kitz" (FW 330.23), fox/vixen appears as "modderren rua" (FW 17.24), "lisa" (FW 245.9), and "fuchs" (FW 328.26) and bunny/rabbit appears in the form of the pun "coney" (FW 68.9), as well as "bunny" (FW 177.36) and multiple other iterations. Indeed, a common Wakean linguistic tactic is to scatter a word across the text in multiple languages.

One familiar metaphor woven through the text is that of the sexually desirable young girl as a cat or, more specifically, a kitten. Here, the association between female sexuality and cats, with

2 The reference (Joyce 1986) will be cited as $U$ with the corresponding episode and line numbers (e.g., 10.327, chapter 10, line 327). Additionally, the reference (Joyce 1964) will be cited as $P$ with the corresponding page numbers (e.g., 152, page 152). 
attendant connotations of innocence, infantilism, desirability and slyness, are invoked. The troubling amalgam of sexual precocity and infantilism ascribed to the character Issy, nymphet daughter of HCE and ALP, is epitomised by her close links to, and occasional representation as, a pet cat, either known as "Buttercup" (FW 561.12) or "Biddles" (FW 561.36).

Just as ALP, the hen and "nightmare", was born of a cow, so, too, is her daughter a nonhuman animal. Her animal counterpart, despite its childish name(s), comes loaded with dual associations. The pet kitten is docile, infantile and in need of protection, yet also associated with sexual desirability and feminine coyness or slyness. Issy, repeatedly configured as a narcissist, is enthralled by her own image. The pet pussycat she refers to may simply be a reflection of herself, infantilised and bestialised. Here, Issy appears to absorb the patriarchal language which circumscribes her as she refers to herself in the third person as both a cat and a filly: "Pussy is never alone, as records her chambrette, for she can always look at Biddles and talk petnames with her little playfilly" (FW 561-62). Yet, as her "lovelilitters" (FW 459.23) indicate, Issy also displays sexual agency; she is a source, as well as an object of, erotic desire.

Pet is also a category to which ALP belongs. In addition to the hen and horse, ALP is also associated with dogs throughout the text. In the text's introduction to HCE, the sleeping giant "Bygmester Finnegan", a rewriting of the lyrics to the folk song "Finnegan's Wake", with clear sexual connotations, follows the patriarch's first appearance. We are told that HCE had a little wife whom he loved/hugged: "He addle liddle phifie Annie ugged the little craythur" (FW 4.22). The phrase echoes disturbingly the name of Alice Liddel, the child who was the apparent model for Alice in Lewis Carroll's Alice in Wonderland. This foreshadows the themes of incest and the blending of mother and daughter characters which will follow in the text. What follows is an explicitly sexual imperative: "Wither hayre in honds tuck up your part inher" (FW 4.29-30). While this is obviously a distortion of the line "Dance to your partner" from the chorus of the song "Finnegan's Wake", it also impels HCE to grab hold of his wife's hair and "tuck up [his] part inher." Furthermore, "honds" here is suggestive of the German word for dog, "hund", which is repeated throughout the text many times in relation to ALP.

The hen associated with ALP reappears in the "Anna Livia Plurabelle" section of the book, as the "kindly fowl" explains what she saw in the dungheap, or "the sack of auld hensyne" (FW 112.08). ALP's manifesto or "mamafesta" (FW 104.4) is both untitled and "has gone by many names at disjointed times". One such name references her repeated characterisation as a farm animal, perhaps lamenting her treatment at the hands of HCE or even Joyce himself: "The Tortor of Tory Island Traits Galasia like his Milchcow" (FW 105.26). The milk cow is one image which clings to ALP. Particularly through German, she is repeatedly linked with milk and cows. ALP's status as farm-animal wife is cemented when she is described as a "farmfrow" (FW 119.10), and, indeed, wives and farm animals are linked elsewhere in the text. Specifically, hens are associated with mistreated wives. The text refers elsewhere to a "poule" (FW 192.13), the French word for hen, in relation to a 1924 Irish Times article Joyce took notes from, entitled "Wife's Petition for Divorce. Allegations of Cruelty" (Deane et al. 2002).

Contrary to the frumpy image invoked by the term "farmfrow" (FW 119.10), ALP also either is enticed by or delights in diffusing a sexual animal odour, possessing a "foul flair for that flayfell foxfetor" (FW 119.10). Furthermore, in the intimation that she revels in the "fetor" of a "fox", ALP transgresses the boundary of docile, exploitable farm animal and takes on wilder, more explicitly sexual characteristics. In this passage of the chapter devoted to her origins and persona, she is linked to her animal-wife precursor, Molly Bloom, through the mention of interior monologue, "the steady monologuy of the interiors" (FW 119.32-33), a form which is feminised and associated specifically with female sexual desire in the Joycean oeuvre. The sexual thoughts which occur within this monologue also threaten "steady monogamy", as ALP, like Molly, wishes for "a tryst someday" (FW 119.30).

The fact that Joyce makes the connection between subjugated farm animals and domestically abused wives, in addition to what sounds like ALP's complaint that her husband treats her like a "milk cow" in her "mamafesta", may indicate that Joyce seeks to expose the mechanisms by which women 
are confined to domestic holding-pens, an exploratory technique documented in the final episode of Ulysses. Like Ulysses, the Wake ends with a female monologue, one which, Devlin argues, "may mitigate the uncompromising otherness of the female principle in the Wake" (Devlin 1991, p. 163). This is the textual moment, as Devlin has noted, where critics suggest we finally hear ALP's voice. ALP's monologue appears to address reconciliatory possibilities, and emphasises her love for her husband HCE, despite his indiscretions and possible crimes, as Christopher DeVault has noted (DeVault 2014, p. 229).

ALP also appears to mock HCE, however, appropriating the derogatory animal imagery directed at her throughout the text and deploying it in order to undermine HCE's pomposity. Here, HCE is defined primarily by his sexual and reproductive capacity, referred to as an "old breeding bradsted" (FW 593.12). HCE is both an "old bleeding bastard" and one who breeds. The conceit of HCE as a stud or bull is reinforced by ALP's mock-grandiose introduction of him as "the eversower of the seeds of light" (FW 593.32). As ALP continues to mock the "Highup Big Cockywocky Sublissimime Autocrat" (FW 612.12) he is animalised by his "bulopent eyes" or bulls' eyes (FW 612.6). ALP also takes this opportunity to further subvert stereotypical animal imagery by referring to her sons Shaun and Shem as docile farm animals. Recalling their earlier appearances as the "Ondt and the Gracehoper", the twins are now "Owned or grazeheifer" (FW 612.36-613.1). Here, HCE becomes the male counterpart to ALP's hen, "Cockalooralooraloomenos" (FW 615.8-9). This marks a moment in the text where a female voice wryly acknowledges the male tendency to reduce women to the level of the beast. ALP's teasing deployment of animal imagery in relation to her husband and sons mocks her treatment as a domestic animal in the text and also echoes Molly Bloom's indignation at being slapped on the buttocks like a mare by her lover Blazes Boylan: "one thing I didn't like his slapping me behind going away so familiarly in the hall though I laughed Im not a horse or an ass am I" (U 18.741).

There are other instances in the text where the deployment of woman-as-animal metaphors ultimately plays into critiques of patriarchy. Indeed, Joyce deploys sexualised and domestic images of women explicitly against patriarchal strictures. Shaun's chastising sermon in III.2, for example, "one of the most accomplished parodies of clerical rhetoric in English literature" (Van Mierlo 2017, p. 76) demonstrates a textual railing against Catholic prescriptions of female modesty. As Shaun chastises Issy, positioning himself as her guardian, his sermon turns increasingly violent and eventually sexual. He refers to her as his "bullin heifer", warning her that he has "the peer of arrams that carry a wallop" (FW 455.24-25). In a scenario in which violence is central, Issy's marginal status as the recipient of Shaun's increasingly aggressive tirade is emphasised by his description of her as a heifer, a submissive and dull object who holds the dual status of commodity and consumable. Relegating her to the level of the non-human and, in particular, invoking an animal which conveys passivity, adds ideological force to his sermon. Furthermore, this passage links back to the abovementioned "Circe" chapter of Ulysses in which feminisation and bestialisation are two mutual and interlinked forms of degradation. Shaun's references to sexual sadism and brothels recall Bloom's humiliation at the hands of Bello, as Shaun implies that he would take sadistic pleasure in riding Issy as a horse is ridden at a rodeo: "You'll give up your ask unbrodhel ways when I make you reely smart. So skelp your budd and kiss the hurt! I'll have plenary sadisfaction, plays the bishops, for your partial's indulgences if your my rodeo gell." (FW 445.6-9).

In Shaun/Jaun's didactic sermon to Issy, there are countless references to animals, and almost all are feminised and at the receiving end of either violent or predatory behaviour. After admonishing Issy for her immodest clothing and behaviour and threatening to punish her, Shaun finally admits his desire: "I waount yiou!" (FW 446.2). Here, Issy's body is characterised, somewhat comically, as not just animalistic, but made of animals. It is also edible, reminiscent of a plum cake, or perhaps also the erotically significant seedcake shared by Leopold and Molly Bloom in Ulysses (U 18.1573). He longs to place his wandering hands in her drawers and cover her in kisses: "positively cover the two pure chicks of your comely plumpchake with zuccherikissings" (FW 446.10-11), so much so that he'd "scare the bats out of the ivfry" (FW 446.11-12). The predatory dynamic of the sermon is further emphasised 
by the final animal image in this passage, where the girls who accompany Issy become prey for the hunter Shaun, who entices them with his "ropes of pearls for gamey girls" (FW 446.26).

Issy is also described as both a cat and a bird in a telling confluence of pet, predator, and prey, which exemplifies the text's portrayal of her as both an innocent victim and a sexual aggressor. Shaun's exclamation "Yip! How's that for scats, mine shatz, for a lovebird?" (FW 451.16) recalls the German word for cat, "katz". Shaun also conflates women with food at several points in the text: "Good-bye, swisstart, goodbye!" (FW 454). As Devlin writes, his "compulsive gluttony ... can be interpreted as a displaced sexual voracity, a substitutive oral pleasure" (Devlin 1991, p. 33). In one instance, however, this conflation becomes explicitly animal-based, as Issy is described as a prime cut of meat. Here, Joyce invokes the historically-entrenched use of meat as a metaphor for prostitution, as Issy is characterised both as a whore and a piece of meat, and Shaun explains that, had he any money, he would spend it on alcohol and access to her flesh: "And what sensitive coin I'd be possessed of at Latouche's, begor, I'd sink it sumtotal, every dolly farting, investments of subdominal oteen at prime cost and I bait you my chancey odcoat aginast the whole ounce you half on your backboard" (FW 450.35-451.3).

The relationship between animality and patriarchal demands of female purity and submissiveness is problematised in Finnegans Wake, as are many of the Free State's cultural dictates. While on the one hand, images of bestial women risk further castigating women's desire as base and degraded, in the section which follows Shaun's sermon, in which Issy responds in an amorous letter, animality is used to signal an unbridled sexuality which imperils Free State constructions of ideal Irish femininity.

Issy's cat persona "Biddles" is associated not only with docility but also reinscribes her as an amorous and sexually provocative figure. In this section of the text, Issy is presented as returning Shaun's erotic gaze. Having carelessly misplaced her "latest lad's lovelilitter" (FW 459.23), Issy composes one of her own in response to Shaun's sermon. The Wakean word "lovelilitter" invokes a female sexuality perilous to Free State patriarchal narratives of femininity in a number, for it is misleadingly innocuous and infantile in its suggestion of "lovely", and simultaneously connotes amorousness, erotic intent, and a flippancy which upsets both cultural notions of female adolescent interest in romance and indeed the text's own construction of Issy as a love-obsessed, vapid adolescent girl. Contrary to dominant cultural narratives of female over-interest in romance, Shaun appears more invested in this erotic-romantic relationship than Issy, and this certainly appears true when her flippant love letters follow the impassioned outburst of his sermon. If these love letters are mere "litter" to Issy, who istheir recipient and author, they are meaningless scraps of waste paper to be thrown away or torn into "flitters" (FW 7.23). Issy may appear to share a similar surface-level romantic disposition to Ulysses' Gerty MacDowell, whose all-consuming romantic fantasies seem fueled by her immersion in female-centred magazines such as the Princess Novelette-what Shaun might refer to as "flitsy tales" (FW 440.18). Indeed, scholars have commented extensively on the links between Gerty and Issy. As Van Mierlo notes, in reading Issy's "lovelilitter", the reader is "invited to link Issy to Gerty MacDowell" (Van Mierlo 2017, p. 103). Also, if one subscribes to the argument that Gerty coyly uses her sexuality to direct and manipulate Bloom's gaze, then it appears that in Issy, Joyce further develops the fantasy figure of the secretly precocious nymphet toying with the sexuality of older men. Certainly, given the sexual playfulness and cunning associated with cats, the description of Issy as a cat as well as the intimation that these letters are mere rubbish to her, might suggest that she toys, catlike, with her brother's incestuous affections.

The word "lovelilitter" also suggests Issy's litterbox, or that of her pet cat Biddles, further reinforcing the sense of love letters as waste and reinscribing textual associations between writing and human waste, while solidifying associations between Issy's sexuality and cats. In addition to conjuring imagery of a litterbox, the word also suggests a litter to which she might give birth. Here, the use of female cat imagery connotes a mature female sexuality which is on its way to motherhood yet still at odds with the designations of passive and modest femininity in the Free State, as Issy cements her desire through the creative (and frequently coded as masculine) act of writing. The act of writing in the Wake has vast repercussions for national and even universal knowledge, as Shem's 
rewriting of Irish history in fecal ink reveals (FW 185-86). The act of writing erotic material, coupled with the textual inscription of the cat and her associations with female sexual precocity, portrays Issy as a sexual aggressor of sorts, a construction which deeply troubles Free State models of femininity rooted in passivity. Of course, the attribution of sexual precocity to Issy, a figure frequently associated with infancy and the recipient of an incestuous gaze, raises wider question about how sexual power dynamics are played out in the book, which are beyond the scope of this article. In this instance, however, it seems that planting in the reader's mind the image of Issy as a kitten, specifically in relation to her self-penned letters of erotic desire, helps to reinforce a sense of a playful feminine sexuality which flagrantly disregards the purity insisted upon by Shaun in his sermon. While such animal imagery at times reinforces stereotypes relating femininity to infantilism and docility, the animality of the cat invokes a wildness and a sexual precocity which, when positioned directly against the controlling forces of Free State Catholicism, produces a rebuttal of sorts. Here, the animal imagery used to degrade Issy in the preceding sermon is refashioned into an articulation of female sexual agency and boldness.

Joyce not only lambasts Free State Catholicism in the sermon episode, but specifically targets the most misogynistic and hypocritical elements of Catholic bishops' fascination with female dress and sexuality, meticulously documented in the Irish national press throughout the 1920s and 1930s. Shaun, posing as a pious bishop or a pompous Free State politician, is revealed as a gross amalgam of hypocrisy and sexual sadism, nearly salivating as he admonishes Issy for wearing high heels and lipstick and cutting Church in order to go on dates. Indeed, as with the text's earlier linking of ALP to an alluringly fragrant she-fox in heat, the text attaches animal imagery to Issy to signal an element of female sexual danger. Shaun fears Issy as much as he admonishes and desires her, and her sexuality is portrayed as profoundly disturbing to him, as it is to their father HCE. Its baseness and unmanageability, emphasised by the repeated association of her with animals, sparks fury in the sexually and morally tortured Shaun, an emblem of Free State patriarchal and Catholic authority.

Undeniably, the trope of the woman-as-animal is inseparable from deeply entrenched connotations of inferiority, and these are never irrelevant in any literary representation of bestial women and feminised animals. Additionally, the livestock metaphors and images deployed in relation to female characters throughout the Wake appear at times to reinforce aspects of the Free State's natalist equation of womanhood with motherhood and domesticity. Specifically, the depiction of female characters as animals risks reinscribing women's confinement to traditionally feminised spaces (the kitchen, the bedroom) and stereotypical roles, such as the life-giving mother that is ALP, and the mentally unstable narcissist and nymphomaniac daughter that is Issy. Elsewhere, however, Joyce draws on animal imagery in order to mount challenges to Free State and patriarchal authority, enacting a reversal of these historically enforced connotations.

Given the Wake's fascination with both the political architecture and the everyday minutiae of the Irish Free State, it is apparent that not only ancient paradigms of subjugated femininity, but the Free State's culturally and historically specific constructions of femininity rooted in purity and chastity, are always present, either implicitly or explicitly, in the text's explorations and representations of femininity. Finnegans Wake, a Free State text, self-consciously emerges from a position of critique, specifically in relation to the sexual politics of the Irish Free State, and its deployment of woman-as-animal trope reveals both its limitations and its impact as a political text. Exploring the deployment of the woman-as-animal reveals new aspects of the text's anti-authoritarian impetus, highlighting a clear Joycean attempt to cut against the sexual politics of the Free State by upending Catholic constructions of chaste femininity. 
Conflicts of Interest: The author declares no conflict of interest.

\section{References}

Adams, Carol J. 1990. The Sexual Politics of Meat. Cambridge: Polity Press.

Antonio, Diane. 1995. Of Wolves and Women. In Animals and Women: Feminist Theoretical Explorations. Edited by Carol J. Adams and Josephine Donovan. Durham: Duke University Press.

Aristotle. 1984. Generation of Animals. In The Complete Works of Aristotle. Edited by Jonathan Barnes. Princeton: Princeton University Press, vol. 1.

Chamberlin, Edward J., and Sander L. Gilman, eds. 1985. Degeneration: The Dark Side of Progress. New York: Columbia University Press.

Deane, Vincent, Daniel Ferrer, and Luca F.P. Crispi, eds. 2002. The Finnegans Wake Notebooks at Buffalo, Volume 6. Amsterdam: Brepols Publishers.

Deleuze, Gilles, and Felix Guattari. 2014. 1730: Becoming-Intense, Becoming-Animal, Becoming-Imperceptible. In A Thousand Plateaus. Translated by Brian Massumi. London: Bloomsbury.

DeVault, Christopher. 2014. Joyce's Love Stories. Surrey: Ashgate.

Devlin, Kimberley J. 1991. The Return of the Repressed: Male Visions and Re-visionings of the Female I/Eye. In Wandering and Return in Finnegans Wake: An Integrative Approach to Joyce's Fictions. Princeton: Princeton University Press.

Donovan, Josephine. 2016. The Aesthetics of Care: On the Literary Treatment of Animals. London: Bloomsbury.

Dunayer, Joan. 1995. Sexist Words, Speciesist Roots. In Animals and Women: Feminist Theoretical Explorations. Edited by Carol J. Adams and Josephine Donovan. Durham: Duke University Press.

Ellmann, Richard. 1983. James Joyce: New and Revised Edition. New York: Oxford University Press.

Ellmann, Maud. 2006. Ulysses: Changing into an Animal. Field Day Review 2: 74-93.

Fordham, Finn. 2007. Lots of Fun at Finnegans Wake: Unravelling Universals. Oxford: Oxford University Press.

Gibson, Andrew, ed. 1994. Introduction. In Reading Joyce's "Circe". Amsterdam: Rodopi.

Haas, Robert. 2014. A James Joyce Bestiary: Animal Symbolism in Ulysses. ANQ: A Quarterly Journal of Short Articles, Notes and Reviews 27: 31-39.

Hayman, David, ed. 2002. A First-Draft Version of Finnegans Wake. Madison: Parallel Press.

Hustvedt, Siri. 2016. The Delusions of Certainty. In A Woman Looking at Men Looking at Women. London: Sceptre. Maria Jolas, ed. 1949. A James Joyce Yearbook. Paris: Transition Press.

Joyce, James. 2002. Finnegans Wake. London: Faber \& Faber.

Joyce, James. 1986. Ulysses. Edited by Hans Walter Gabler, Wolfhard Steppe and Claus Melchior. New York: Random House.

Joyce, James. 1964. A Portrait of the Artist as a Young Man. Corrected from Dublin Holograph by Chester G. Anderson; Edited by Richard Ellmann. New York: Viking Press.

Luddy, Maria. 2007. "Hopeless cases": Prostitution and sexual danger in the Irish Free State, 1922-1940. In Prostitution and Irish Society, 1800-1940. Cambridge: Cambridge University Press.

Meaney, Gerardine. 2010. The Foreigner Within. In Gender, Ireland and Cultural Change: Race, Sex and Nation. New York: Routledge.

Van Mierlo, Chrissie. 2017. James Joyce and Catholicism: The Apostate's Wake. London: Bloomsbury.

Norris, Margot. 2014. The Animals of James Joyce's Finnegans Wake. Modern Fiction Studies 60: 527-43. [CrossRef]

Peterson, Christopher. 2013. Bestial Traces: Race, Sexuality, Animality. New York: Fordham University Press.

Plumwood, Val. 1993. Feminism and the Mastery of Nature. London: Routledge.

Rando, David. 2009. The Cat's Meow: Ulysses, Animals, and the Veterinary Gaze. James Joyce Quarterly 46: 529-43. [CrossRef]

Rodriguez, Irene Lopez. 2009. Of Women, Bitches, Chickens, and Vixens: Animal Metaphors for Women in English and Spanish. Culture, Language and Representation VII: 77-100.

Sam Slote, and Luca Crispi, eds. 2007. How Joyce Wrote Finnegans Wake: A Chapter by Chapter Genetic Guide. Madison: University of Wisconsin Press. 
The Irish Christian Brothers. 1924. The Irish Independent, January 22.

Valiulis, Maryann Gialenella. 1995. Power, Gender, and Identity in the Irish Free State. Journal of Women's History 6: 96-106. [CrossRef]

Yuval-Davis, Nira, and Floya Anthias, eds. 1989. Woman-Nation-State. Basingstoke: Palgrave Macmillan.

(C) 2017 by the author. Licensee MDPI, Basel, Switzerland. This article is an open access article distributed under the terms and conditions of the Creative Commons Attribution (CC BY) license (http:/ / creativecommons.org/licenses/by/4.0/). 